\title{
Fuel consumption efficiency of an agricultural tractor equipped with continuously variable transmission
}

\author{
Marcelo Silveira de Farias ${ }^{1}$ José Fernando Schlosser ${ }^{2}$ Pilar Linares $^{3}$ Juan Paulo Barbieri ${ }^{2}$ \\ Giácomo Müller Negri ${ }^{2}$ Luis Fernando Vargas de Oliveira ${ }^{4}$ Iury Iago Port Rüdell ${ }^{2}$
}

\begin{abstract}
'Departamento de Ciências Agronômicas e Ambientais (DCAA), Universidade Federal de Santa Maria (UFSM), Campus Frederico Westphalen, 98400-000, Frederico Westphalen, RS, Brasil. E-mail: silveira_farias@hotmail.com. Corresponding author.

${ }^{2}$ Departamento de Engenharia Rural (DER), Centro de Ciências Rurais (CCR), Universidade Federal de Santa Maria (UFSM), Santa Maria, RS, Brasil.

${ }^{3}$ Departamento de Ingeniería Agroforestal, Escuela Técnica Superior de Ingenieros Agrónomos (ETSIA), Universidad Politécnica de Madrid (UPM), Madrid, España.

${ }^{4}$ Departamento de Engenharia Mecânica (DEM), Centro de Tecnologia (CT), Universidade Federal de Santa Maria (UFSM), Santa Maria, RS, Brasil.
\end{abstract}

ABSTRACT: The correct choice of modern power transmissions can help farmers decrease production costs. The following research aimed to assess fuel consumption efficiency of an agricultural tractor equipped with continuously variable transmission, at different travel speed and load levels applied on the tractor drawbar. Standard procedure has been applied considering six load levels (30; 40; 50; 60; 70 and $80 \%$ of Q0) by means of breaking with a dynamometer car instrumented in a concrete test track, at three travel speeds $\left(5.16 ; 7.29\right.$ and $\left.10.48 \mathrm{~km} h^{-1}\right)$. Throughout the experiment, engine speed, traction force and hourly fuel consumption were monitored. The results indicated that there was an average increase of 2.67; 2.82; and 2.61 $\mathrm{h} \mathrm{h}^{-1}$ in the hourly fuel consumption for each 10\% increase in the load level on the tractor, for travel speed of 5.16; 7.29 and $10.48 \mathrm{~km} \mathrm{~h}^{-1}$, respectively. In general, the specific fuel consumption of the tractor decreased as the load levels and the travel speeds were increased.

Key words: tractor testing, load levels, CVT transmission, specific fuel consumption.

Eficiência no consumo de combustível de um trator agrícola equipado com transmissão continuamente variável

RESUMO: A escolha correta de modernas transmissões de potência pode auxiliar os agricultores a diminuírem os custos de produção. Este trabalho teve como objetivo avaliar a eficiência de consumo de combustivel de um trator agrícola equipado com transmissão continuamente variável, em diferentes velocidades de deslocamento e cargas parciais impostas à barra de tração do trator. Para a avaliação utilizou-se procedimento normalizado, com aplicação de seis cargas parciais (30; 40; 50; 60; 70 e 80\% de Q0), por meio da frenagem com um carro dinamométrico instrumentado, em pista de concreto, em três velocidades de deslocamento $\left(5,16 ; 7,29\right.$ e 10,58km $\left.\mathrm{h}^{-1}\right)$. Durante a condução do experimento, monitoraram-se a rotação do motor, a força de tração e o consumo horário de combustivel. Os resultados indicaram que houve acréscimo, médio, de 2,67; 2,82; e 2,61L $\mathrm{h}^{-1}$ no consumo horário de combustível para o aumento de cada $10 \%$ na carga imposta ao trator, para as velocidades de 5,16; 7,29 e 10,48km $\mathrm{h}^{-1}$, respectivamente. Ao considerar o consumo especifico do trator, de forma geral, diminuiu à medida que as cargas parciais e as velocidades de deslocamento foram incrementadas.

Palavras-chave: ensaio de trator, cargas parciais, transmissão CVT, consumo específico de combustivel.

\section{INTRODUCTION}

Agriculture is one of the economic sectors that need to take appropriate decisions in order to reduce the high fuel consumption and; therefore, environmental pollution (PÉREZ-MARTÍNEZ, 2012). In terms of potential to reduce production costs, agricultural mechanization can be considered as the main factor (PELOIA \& MILAN, 2010).
According to SIEMENS \& BOWERS (1999), fuel costs represent at least $16 \%$, reaching $45 \%$ of the hourly costs of an agricultural tractor, and this represents the largest share of the total cost of an hour of machine work.

As a result of high production costs involving agricultural mechanization, new technologies have been developed in an attempt to reduce these costs and increase energy efficiency in 
the use of agricultural tractors. Thus, CVT technology (Continuously Variable Transmission), recently available in tractors sold in the Brazilian market paved the way for a comprehensive management of engine and transmission, as well as the development of driving strategies that improve productivity and user's comfort (LINARES et al., 2010).

These transmissions are equipped with a control system that can adjust the gear ratio and engine speed so that it can work at a point of maximum fuel efficiency for certain conditions (RENIUS \& RESCH, 2005). Thus, according to GOMEZ (2003), CVT transmissions offer the potential to achieve maximum engine efficiency.

This type of transmission has been well received by farmers because of its advantages, such as comfort, ease handling and response to diverse needs (LINARES et al., 2010). However, studies assessing the energy efficiency of a tractor equipped with CVT transmission are necessary to be conducted in order to recommend its use, according to the traction demand which it will be submitted to, as well as, contribute to the train operators and consolidate learning of such technologies.

This study aimed to evaluate the fuel consumption efficiency of a tractor equipped with CVT transmission, at different travel speeds and load levels to the drawbar.

\section{MATERIALS AND METHODS}

\section{Research tractor}

The experiment was conducted in a concrete test track at the Mechanic Agriculture Station, an official laboratory of the Ministry of Agriculture, Food and Environment of Spain. A Massey Ferguson tractor, model MF 7618 DynaVT, was used equipped with a four stroke Diesel cycle engine model 66 AWI 695 with six cylinders, volumetric displacement of $6,596 \mathrm{~cm}^{3}$ and powered by turbocharger with an intercooler. According to the test report, maximum power is $113.4 \mathrm{~kW}$ (154.2hp) at 2000rpm (IRSTEA, 2013). Tractor was equipped with a CVT transmission, which allowed infinite gear ratios, and was conducted using the automatic mode.

\section{Data acquisition}

Indirectly, the engine speed was obtained by using a magnetic tachometer installed in the power take-off (PTO) of the tractor. Fuel consumption was measured using a volumetric flow meter located on the dynamometer car coupled to the tractor, which function was to impose on the drawbar load levels controllably dosed and allocate the instrumental measurement. Car braking is given by means of a hydraulic circuit through a variable displacement pump. The car had a maximum capacity of traction $147.15 \mathrm{kN}(15,000 \mathrm{kgf})$ and its mass for the experiment was $17,850 \mathrm{~kg}$. The experiment layout is shown in figure 1.

Before the experiment was carried out, the engine run in was conducted applying an electric dynamometer break, coupled to the tractor by the PTO, being applied for a period of 30 hours load on the engine equivalent to $30 \%$ of rated power reported by the manufacturer.

\section{Test method and procedure}

Since the power in the drawbar is the product of travel speed and traction force, thus varying one of these parameters is possible to determine the power range to be evaluated. In this study, three shift speeds were applied, which ranged from 5 to $11 \mathrm{~km} \mathrm{~h}^{-1}$, determined to contemplate the variety of agricultural operations in the field.

Load levels applied on the tractor were obtained based on the official test report Number 17143 (IRSTEA, 2013). For each selected travel speed, the traction force (Q0) corresponding to the maximum power at the drawbar was assumed. Thus, it was obtained the $52.10 \mathrm{kN}$ traction force to the speed $5.16 \mathrm{~km} \mathrm{~h}^{-1} ; 42.80 \mathrm{kN}$ for $7.29 \mathrm{~km} \mathrm{~h}^{-1}$ and $33.50 \mathrm{kN}$ for the speed of $10.48 \mathrm{~km} \mathrm{~h}^{-1}$.

Considering the fact that a single tractor can pull various implements with different power requirements six load levels $(30,40,50,60,70$, and $80 \%$ of Q0) were applied to the drawbar for each travel speed. According to RICKETTS \& WEBER (1961), the so-called "heavy" agricultural operations require between $56 \%$ and $97 \%$ of the maximum power available on the tractor at maximum engine acceleration.

\section{Experimental and statistical procedures}

The engine speed (rpm) and hourly consumption $\left(\mathrm{L} \mathrm{h}^{-1}\right)$ and specific $\left(\mathrm{g} \mathrm{kWh}^{-1}\right)$ to engine fuel were analyzed in a factorial scheme $(3 \times 6)$, from the interaction of three travel speeds and six load levels applied on the tractor. Three replications were conducted, at a total of 54 experimental units, thus composing a completely randomized design experiment. After the evaluations, the data were analyzed for normality and homoscedasticity. Then, all variables were subjected to analysis of variance (ANOVA). In case of significance, means were analyzed by Tukey's test $(\mathrm{P} \leq 0.05)$ applying Sisvar software, version 5.3 (FERREIRA, 2011). 


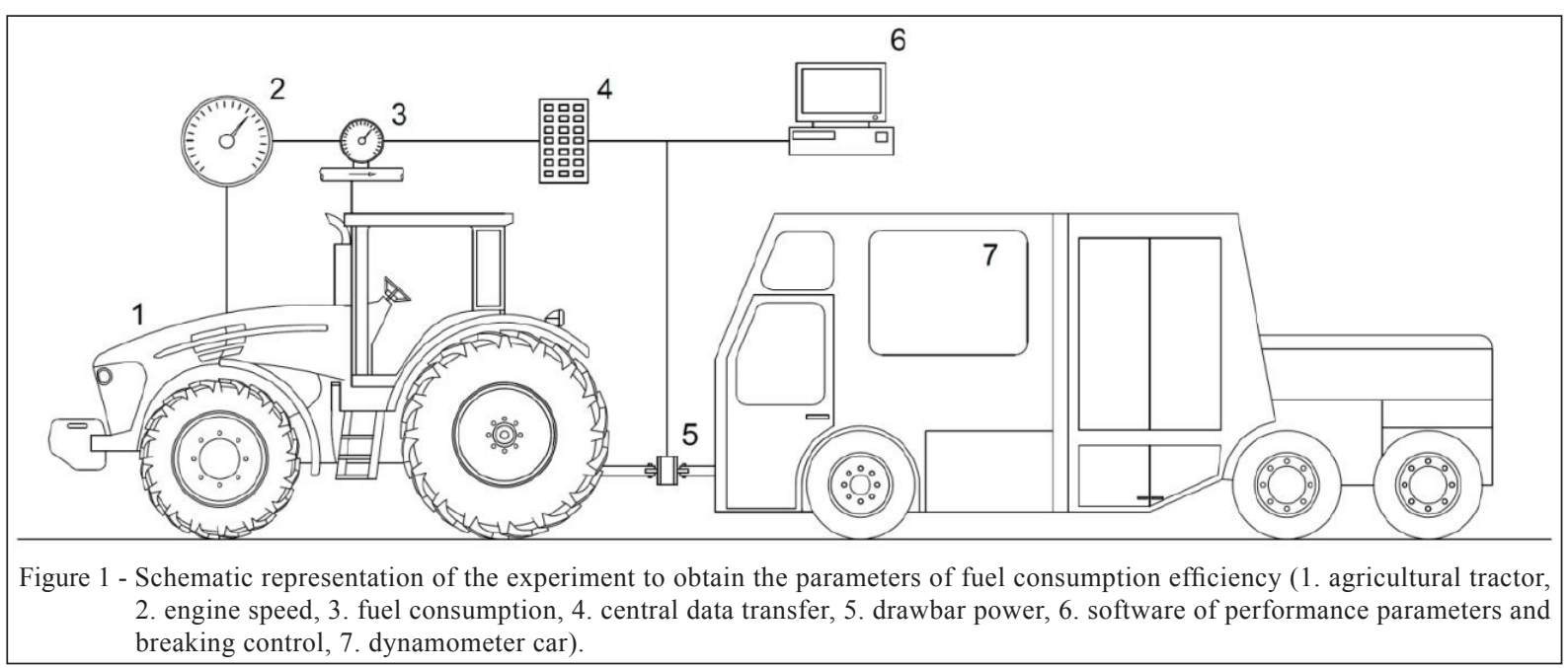

\section{RESULTS AND DISCUSSION}

The summary of the ANOVA of the results of engine speed, hourly and specific fuel consumption at different travel speeds and load levels applied on the tractor, is shown in table 1. From these results, there was a significant effect $(\mathrm{P} \leq 0.05)$ of the interaction between the factors in the analyzed parameters. Low values of coefficient of variation $(\mathrm{CV})$ representing the standard deviation expressed as a percentage of the average indicated a probable accuracy of the experiment.

\section{Engine speed}

Engine speed had different behaviors for the three traveling speeds measured explained by polynomial equations (Figure 2A). However, the engine characteristic to increase its rotation due to the increase of the load levels is the same for all three speeds (Table 2). This is a major feature of CVT transmissions, since in an attempt to keep the pre-set working speed there are increases in engine speed.

According to the detected load and the travel speed programmed by the user, the engine speed will be higher if you need more power or less if the work does not require high traction force (ALONSO, 2014). Thus, engine performance is optimized, since in small traction force circumstances such as transport, for example, an electronic control unit will reduce the rotation of the engine, where as in situations requiring the acceleration, the engine will work at rotational maximum power (RENIUS \& RESCH, 2005).

Depending on the joint management of the engine and transmission provided by the CVT transmission, it is clear the possibility of working at lower engine speeds and appropriate travel speeds in order to efficiently use the fuel in agricultural operations, provided there is no overload as to reduce the reserve engine torque.

Table 1 - Summary of the ANOVA for the engine speed (rpm), hourly $\left(\mathrm{L} \mathrm{h}^{-1}\right)$ and specific $\left(\mathrm{g} \mathrm{kWh}^{-1}\right)$ fuel consumption parameters.

\begin{tabular}{|c|c|c|c|c|}
\hline \multirow{2}{*}{ Sources of variation } & \multirow{2}{*}{ Degrees of freedom } & \multicolumn{3}{|c|}{---Average squares--- } \\
\hline & & Engine speed & Hourly fuel consumption & Specific fuel consumption \\
\hline Travel speed $(\mathrm{T})$ & 2 & 44709.33 & 25.67 & 335.32 \\
\hline Load level (L) & 5 & 116896.25 & 229.79 & 3760.66 \\
\hline$T \times L^{*}$ & 10 & 7371.86 & 0.21 & 81.32 \\
\hline Residue & 36 & 505.29 & 0.05 & 9.86 \\
\hline $\mathrm{Fc}(\mathrm{T} \times \mathrm{L})$ & & 14.59 & 4.06 & 8.25 \\
\hline CV $(\%)$ & & 1.67 & 1.25 & 1.03 \\
\hline
\end{tabular}

"Differ statistically $(\mathrm{P} \leq 0.05)$. 


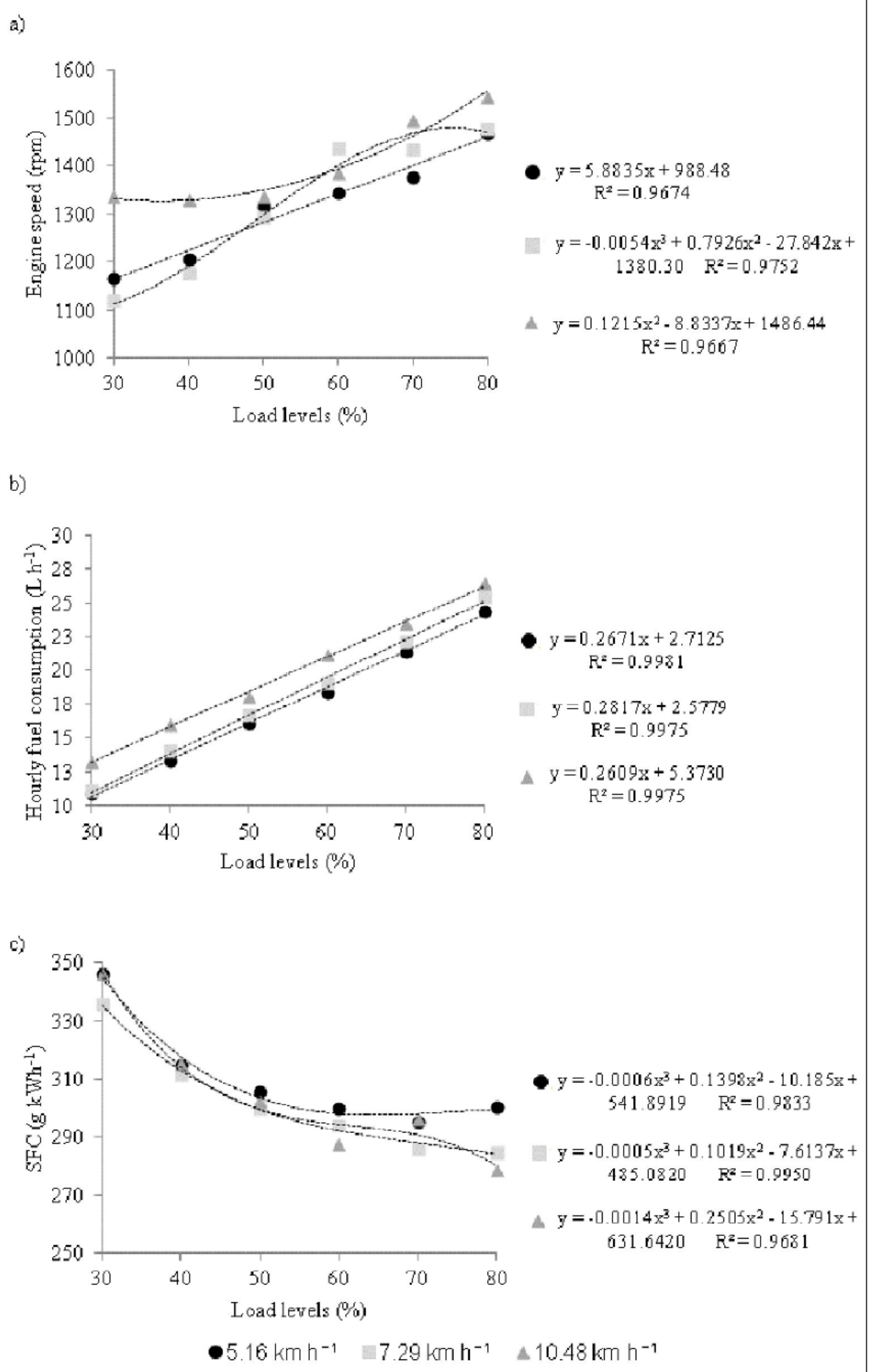

Figure 2 - (a) Engine speed; (b) hourly and (c) specific fuel consumption (SFC) regarding the load levels applied to the tractor for three travel speeds $\left(5.16 ; 7.29\right.$ and $\left.10.48 \mathrm{~km} \cdot \mathrm{h}^{-1}\right)$. 
Table 2 - Average values of engine speed (rpm), hourly $\left(\mathrm{L} \mathrm{h}^{-1}\right)$ and specific $\left(\mathrm{g} \mathrm{kWh}^{-1}\right)$ fuel consumption (SFC) for three travel speeds and six load levels applied to the tractor.

\begin{tabular}{|c|c|c|c|c|c|c|}
\hline \multirow[t]{2}{*}{ Travel speeds $\left(\mathrm{km} \mathrm{h}^{-1}\right)$} & \multicolumn{6}{|c|}{----Load levels (\%)--- } \\
\hline & 30 & 40 & 50 & 60 & 70 & 80 \\
\hline \multicolumn{7}{|c|}{ - } \\
\hline 5.16 & $1164.89^{\mathrm{Ba}}$ & $1203.89^{\mathrm{Aa}}$ & $1315.80^{\mathrm{Ab}}$ & $1342.95^{\mathrm{Abc}}$ & $1378.23^{\mathrm{Ac}}$ & $1466.70^{\mathrm{Ad}}$ \\
\hline 7.29 & $1119.08^{\mathrm{Aa}}$ & $1176.23^{\mathrm{Ab}}$ & $1292.84^{\mathrm{Ac}}$ & $1436.70^{\mathrm{Bd}}$ & $1434.67^{\mathrm{Bd}}$ & $1479.71^{\mathrm{Ad}}$ \\
\hline 10.48 & $1334.19^{\mathrm{Ca}}$ & $1329.58^{\mathrm{Ba}}$ & $1335.68^{\mathrm{Aa}}$ & $1384.39^{\mathrm{Aa}}$ & $1494.07^{\mathrm{Cb}}$ & $1542.63^{\mathrm{Bb}}$ \\
\hline \multicolumn{7}{|c|}{ 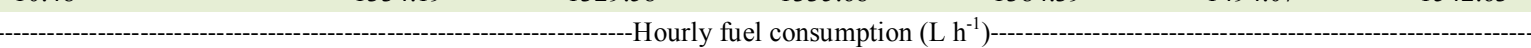 } \\
\hline 5.16 & $10.90^{\mathrm{Aa}}$ & $13.38^{\mathrm{Ab}}$ & $16.05^{\mathrm{Ac}}$ & $18.37^{\mathrm{Ad}}$ & $21.37^{\mathrm{Ae}}$ & $24.34^{\mathrm{Af}}$ \\
\hline 7.29 & $11.11^{\mathrm{Aa}}$ & $14.02^{\mathrm{Bb}}$ & $16.62^{\mathrm{Bc}}$ & $19.04^{\mathrm{Bd}}$ & $22.19^{\mathrm{Be}}$ & $25.45^{\mathrm{Bf}}$ \\
\hline 10.48 & $13.29^{\mathrm{Ba}}$ & $15.99^{\mathrm{Cb}}$ & $18.02^{\mathrm{Cc}}$ & $21.13^{\mathrm{Cd}}$ & $23.44^{\mathrm{Ce}}$ & $26.46^{\mathrm{Cf}}$ \\
\hline \multicolumn{7}{|c|}{ } \\
\hline 5.16 & $346.21^{\mathrm{Bd}}$ & $314.72^{\mathrm{Ac}}$ & $305.71^{\mathrm{Ab}}$ & $299.98^{\mathrm{Bab}}$ & $295.11^{\mathrm{Ba}}$ & $300.57^{\mathrm{Bab}}$ \\
\hline 7.29 & $335.98^{\mathrm{Ad}}$ & $311.82^{\mathrm{Ac}}$ & $299.91^{\mathrm{Ab}}$ & $293.92^{\mathrm{Bb}}$ & $285.91^{\mathrm{Aa}}$ & $284.62^{\mathrm{Aa}}$ \\
\hline 10.48 & $346.30^{\mathrm{Be}}$ & $315.16^{\mathrm{Ad}}$ & $302.26^{\mathrm{Ac}}$ & $287.29^{\mathrm{Ab}}$ & $296.26^{\mathrm{Bc}}$ & $278.70^{\mathrm{Aa}}$ \\
\hline
\end{tabular}

*Averages followed by the same capital letters in the column and low case letters in the line do not differ between each other by Tukey test, considering the nominal value of significance at $5 \%$.

\section{Hourly fuel consumption}

Hourly fuel consumption had the same behavior for all three travel speeds studied (Figure 2B). From the linear regression equation presented in this figure, one can expect average increase of 2.67; 2.82 and $2.61 \mathrm{~L} \mathrm{~h}^{-1}$ in fuel consumption for each $10 \%$ increase in the load level on the tractor, for travel speeds of $5.16 ; 7.29$ and $10.48 \mathrm{~km} \mathrm{~h}^{-1}$, respectively. Results which corroborated those reported by KIM et al. (2011), which described that the fuel consumption varies according to the type and percentage of the imposed engine load.

From the results obtained by Tukey's test (Table 2), it is observed that the load levels differed in six distinct groups in the three evaluated travel speeds. As load levels were increased, fuel consumption was higher confirming the data obtained by HOWARD et al. (2013), which described the hourly fuel consumption is a linear function of power in the drawbar.

For each travel speed, there is an increase in the hourly fuel consumption of 223.30; 229.07 and $199.10 \%$ when compared to the load of $80 \%$ compared to $30 \%$ load, for travel speeds of $5.16 ; 7.29$ and $10.48 \mathrm{~km} \mathrm{~h}^{-1}$, respectively. The speed of $10.48 \mathrm{~km}$ $\mathrm{h}^{-1}$ is the one with the lowest percentage increase in hourly fuel consumption (199.10\%), but from the first applied load level is the travel speed with the highest consumption (Table 2).

According to the results of a test conducted at the University of Nebraska, a tractor equipped with CVT transmission conducted in automatic mode was more economical than another tractor equipped with mechanical transmission, when the power in the drawbar was $76-81 \%$ of the maximum power (HOWARD et al., 2013). There is no need for high power, transmission ratio changes, and the engine speed is reduced, but the working travel speed is kept constant, allowing for greater efficiency in fuel consumption (ALONSO, 2014).

\section{Specific fuel consumption}

The fuel economy using the tractor with CVT transmission in automatic mode increased as the load level applied on the tractor was also higher (Figure 2C), corroborating the data obtained by ASAE (2006), which describes the specific fuel consumption is a nonlinear function of the power in the drawbar. The adjustment of the polynomial regression curves and their equations have high coefficient of determination $\left(R^{2}>0.9681\right)$, which ensures safety in inferences at all travel speeds assessed.

By having a careful analysis of the effect of increasing the load levels for each travel speed it is reported that, for travel speeds of 5.16 and $7.29 \mathrm{~km} \mathrm{~h}^{-1}$, there is no specific consumption difference between the highest loads (70 and 80\%) and intermediate loads (50 to $60 \%$ ), but for smaller ones (30 to $40 \%$ ) there is difference for specific consumption (Table 2). For the $80 \%$ load level using a travel speed of $10.48 \mathrm{~km} \mathrm{~h}^{-1}$, the specific fuel consumption is reduced by almost $20 \%$, from $346.30 \mathrm{~g} \mathrm{kWh}^{-1}$ to $278.70 \mathrm{~g} \mathrm{kWh}^{-1}$. 
Although there was a linear increase of fuel volume consumed per hour by the engine, the power developed in the tractor drawbar also increased, explaining the lower specific fuel consumption (ACUÑA et al., 1995). This power, according to SALVADOR et al. (2009), is a function of the traction force and travel speed.

Low values of specific fuel consumption mean simultaneous optimization of engine performance, efficiency in traction and the adequacy of the implement to the power supply (LYNE et al., 1984). The existence of an inverse relationship between the specific fuel consumption and load levels applied on the tractor reinforce this claim.

In assessing the performance in a concrete test track of an agricultural tractor with CVT transmission, COFFMAN et al. (2010) stated that, in the automatic mode, it was possible to significantly reduce fuel consumption compared to manual mode. Also according to the authors, CVT transmission in automatic mode has advantages over manual mode for low power in the drawbar, and the time and specific fuel consumption were similar for the two modes of operation, when the power developed in the drawbar was greater.

Tractors with travel speed automatic transmission allow better use of engine power, so these models, besides having a more comfortable handling for the operator, provide improved fuel economy compared to models without variation of automatic travel speeds (ALONSO, 2014). Within a global economy in which Brazilian agriculture operates, the importance and dissemination of information on the performance of farming machines are essential for taking decisions, especially those related to the optimization of fuel efficiency (MONTEIRO, 2011).

\section{CONCLUSION}

There is a direct linear relationship between the hourly fuel consumption and power in the drawbar for each travel speed. The higher load level applied on the tractor, the higher is the engine fuel consumption. In general, the specific fuel consumption of the tractor with continuously variable transmission decreases as the load levels and travel speeds are increased, reflecting energy production with low fuel consumption.

\section{ACKNOWLEDGEMENTS}

The authors are grateful to the Coordenação de Aperfeiçoamento de Pessoal de Nível Superior (CAPES) for financial support; to the Conselho Nacional de Desenvolvimento Científico e Tecnológico $(\mathrm{CNPq})$ for research productivity scholarship of the second author. Also to the engineers of tests and mechanics of the Estación de Mecánica Agrícola (EMA) by the total dedication to work.

\section{REFERENCES}

ACUÑA, R.R.D. et al. Comparação do coeficiente de tração e da eficiência tratória de um trator agrícola obtidos pela equação de Wismer e Luth e por ensaios de campo. Pesquisa Agropecuária Brasileira, v.30, n.4, p.523-530, 1995. Available from: <http:// seer.sct.embrapa.br/index.php/pab/article/view/4335/1621>. Accessed: Aug. 30, 2016.

ALONSO, M.J.G. Descripción y estudio técnico de las estrategias de conducción de los tractores Deutz-Fahr. 2014. 198f. Trabajo fin de carrera (Departamento de Ingeniería Rural) Universidad Politécnica de Madrid, Escuela Técnica Superior de Ingenieros Agrónomos, Madrid, Espanha.

ASAE (AMERICAN SOCIETY OF AGRICULTURAL ENGINEERS). ASAE D497.5: Agricultural Machinery Management. St Joseph, 2006. p.343-349.

COFFMAN, B.A. et al. Testing fuel efficiency of a tractor with a continuously variable transmission. Applied Engineering in Agriculture, v.26, n.1, p.31-36, 2010. Available from: <http:// elibrary.asabe.org/abstract.asp?aid $=29468 \& \mathrm{t}=2$ \& redir $=$ aid $=29468$ $\&$ confalias $=\&$ redir $=[$ volume $=26 \&$ issue $=1 \& \operatorname{conf}=$ aeaj\&orgconf $=$ aeaj2010]\&redirType $=$ toc_journals.asp\&redirType $=$ toc_journals . asp>. Accessed: Aug. 31, 2016. doi: 10.13031/2013.29468.

FERREIRA, D.F. Sisvar: a computer statistical analysis system. Ciência e Agrotecnologia, v.35, n.6, p.1039-1042, 2011. Available from: <http:/www.scielo.br/scielo.php?script=sci ar ttext\&pid $=$ S1413-70542011000600001>. Accessed: Aug. 30, 2016. doi: 10.1590/S1413-70542011000600001.

GOMEZ, M.M. A continuously variable power-split transmission in a hybrid electric sport utility vehicle. 2003. 120f. Thesis (Department of Mechanical and Aerospace Engineering). West Virginia University, Morgantown, West Virginia, USA.

HOWARD, C.N. et al. Testing the fuel efficiency of tractors with continuously variable and standard geared transmissions. Transactions of the ASABE, v.56, n.3, p.869-879, 2013. Available from: <http://elibrary.asabe.org/abstract.asp?aid=4274 $1 \& \mathrm{t}=3 \&$ dabs $=\mathrm{Y} \&$ redir $=\&$ redirType $=>$. Accessed: Aug. 31, 2016. doi: $10.13031 /$ trans.56.10222.

IRSTEA (UNITÉ DE RECHERCHE TECHNOLOGIES POUR LA SÉCURITÉ ET LES PERFORMANCES DES AGROÉQUIPEMENTS - CENTRE D'ANTONY). Test report $N^{\circ}$ 17143: OECD performance test of an agricultural tractor. Paris, 2013. 32p.

KIM, S.C. et al. Prediction of fuel consumption of agricultural tractors. Applied Engineering in Agriculture, v.27, n.5, p.705709, 2011. Available from: <http://elibrary.asabe.org/abstract.asp? aid $=39565 \& \mathrm{t}=2 \&$ redir $=\&$ redirType $=>$. Accessed: Aug. 31, 2016. doi: $10.13031 / 2013.39565$.

LINARES, P. et al. Design parameters for continuously variable power-split transmissions using planetaries with 3 actives shafts. Journal of Terramechanics, v.47, p.323-335, 2010. 
Available from: <http://www.sciencedirect.com/science/article/ pii/S0022489810000364>. Accessed: Aug. 31, 2016. doi: 10.1016/j.jterra.2010.04.004.

LYNE, P.W.L. et al. Effect of tire and engine parameters on efficiency. Transactions of the ASABE, v.27, n.1, p.5-11, 1984.

MONTEIRO, L.A. Desempenho operacional e energético, segundo a norma OECD - Code 2 de dois tratores agrícolas 4x2 TDA com motores de $132 \mathrm{~kW}$ em pista de concreto e solo agrícola. 2011.92f. Tese (Doutorado em Agronomia) - Universidade Estadual Paulista "Júlio de Mesquita Filho", Botucatu, SP.

PELOIA, P.R.; MILAN, M. Proposta de um sistema de medição de desempenho aplicado à mecanização agrícola. Revista Engenharia Agrícola, v.30, n.4, p.681-691, 2010. Available from: <http://www.scielo.br/scielo.php?script=sci_arttext\&pid $=$ S0100-69162010000400012 $>$. Accessed: Aug. 31, 2016. doi: 10.1590/S0100-69162010000400012.

PÉREZ-MARTÍNEZ, P.J. Energy consumption and emissions from the road transport in Spain: a conceptual approach.
Transport, v.27, n.4, p.383-396, 2012. Available from: $<$ http://www.tandfonline.com/doi/abs/10.3846/16 484142.2012.751051>. Accessed: Aug. 30, 2016. doi: $10.3846 / 16484142.2012 .751051$.

RENIUS, K.T.; RESCH, R. Continuously variable tractor transmissions. St. Joseph, EUA: ASAE, 2005. (Distinguished lecture Series, 29).

RICKETTS, C.J.; WEBER, J.A. Tractor engine loading. Agricultural Engineering, v.42, n.5, p.236-239, 1961.

SALVADOR, N. et al. Consumption of fuel in different systems of periodical preparation performed before and after the subsoiling operation. Ciência e Agrotecnologia, v.33, n.3, p.870-874, 2009. Available from: <http:/www.scielo.br/scielo.php?script=sci arttext\&pid $=$ S1413-70542009000300029 $>$. Accessed: Aug. 30, 2016. doi: 10.1590/S1413-70542009000300029.

SIEMENS, J.C.; BOWERS, W.W. Machinery management: how to select machinery to fit the real needs of farm managers. East Moline: John Deere, 1999. 5p. 